\title{
Some aspects of the family Chromodorididae (Opisthobranchia: Nudibranchia) from Brazil, with description of a new species
}

\author{
MARTA DOMÍNGUEZ ${ }^{1}$, FRANCISCO J. GARCÍA ${ }^{2}$ and JESÚS S. TRONCOSO ${ }^{1}$ \\ ${ }^{1}$ Depto. Ecología y Biología Animal, Facultad Ciencias del Mar, Universidade de Vigo, Lagoas-Marcosende, \\ E-36200 Vigo, Spain. E-mail: malvarez@uvigo.es \\ ${ }^{2}$ Depto. Fisiología y Zoología; Facultad Biología; Universidad Sevilla; Avda. Reina Mercedes, 6; Apdo. 1095, \\ 41080 Sevilla, Spain.
}

\begin{abstract}
SUMMARY: This paper describes a study of the nudibranchs from the family Chromodorididae Bergh, 1891 that were sampled in several expeditions along the coast of Rio de Janeiro, São Paulo and Fernando de Noronha (Brazil). A total of eight species of this family were studied and a new species, Chromodoris paulomarcioi n. sp., is described. The taxon Hypselodoris picta lajensis Troncoso, García and Urgorri, 1998, is proposed for consideration within the taxonomic category of species, and new records for some species are provided.
\end{abstract}

Keywords: Nudibranchia, Chromodorididae, Brazil, Chromodoris paulomarcioi n. sp., Hypselodoris lajensis.

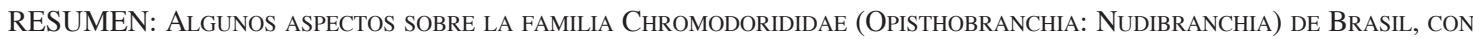
LA DESCRIPCIÓN DE UNA NUEVA ESPECIE. - En este trabajo se hace un estudio de los nudibranquios pertenecientes a la familia Chromodorididae Bergh, 1891 encontrados durante varias campañas de muestreo en el litoral de Río de Janeiro, São Paulo y Fernando de Noronha (Brasil); fue estudiado un total de ocho especies de esta familia con descripción de una nueva especie, Chromodoris paulomarcioi n.sp. El taxón Hypselodoris picta lajensis Troncoso, García and Urgorri, 1998, es elevado a la categoría taxonómica de especie, y se proporcionan nuevas citas para algunas de las especies halladas.

Palabras clave: Nudibranchia, Chromodorididae, Brasil, Chromodoris paulomarcioi n. sp., Hypselodoris lajensis.

\section{INTRODUCTION}

Von Ihering (1886) drew up a list with descriptions of six nudibranch species from the western Atlantic Ocean. Later, MacFarland (1909) described seven species collected during the Branner Agassiz expedition in Brazil, but none of them belonged to the family Chromodorididae.

The most important contribution to the knowledge of Brazilian opisthobranchs was made by Ernest and Eveline Marcus, who studied specimens from the western Atlantic in great detail and found most of the currently known species from this zone. They published many papers that resulted from the samples collected from the Brazilian coast, mainly in São Paulo. Matthews and Kempf (1970) published a list of molluscs from the Fernando de Noronha Archipelago; they cited 160 species but only four of these were opisthobranchs. In 1977, Eveline Marcus published a checklist of the western Atlantic warm water opisthobranchs. Some recent contributions were provided by Ortea et al. (1994), Pola et al. (2005), and Padula and Absalão (2005). 


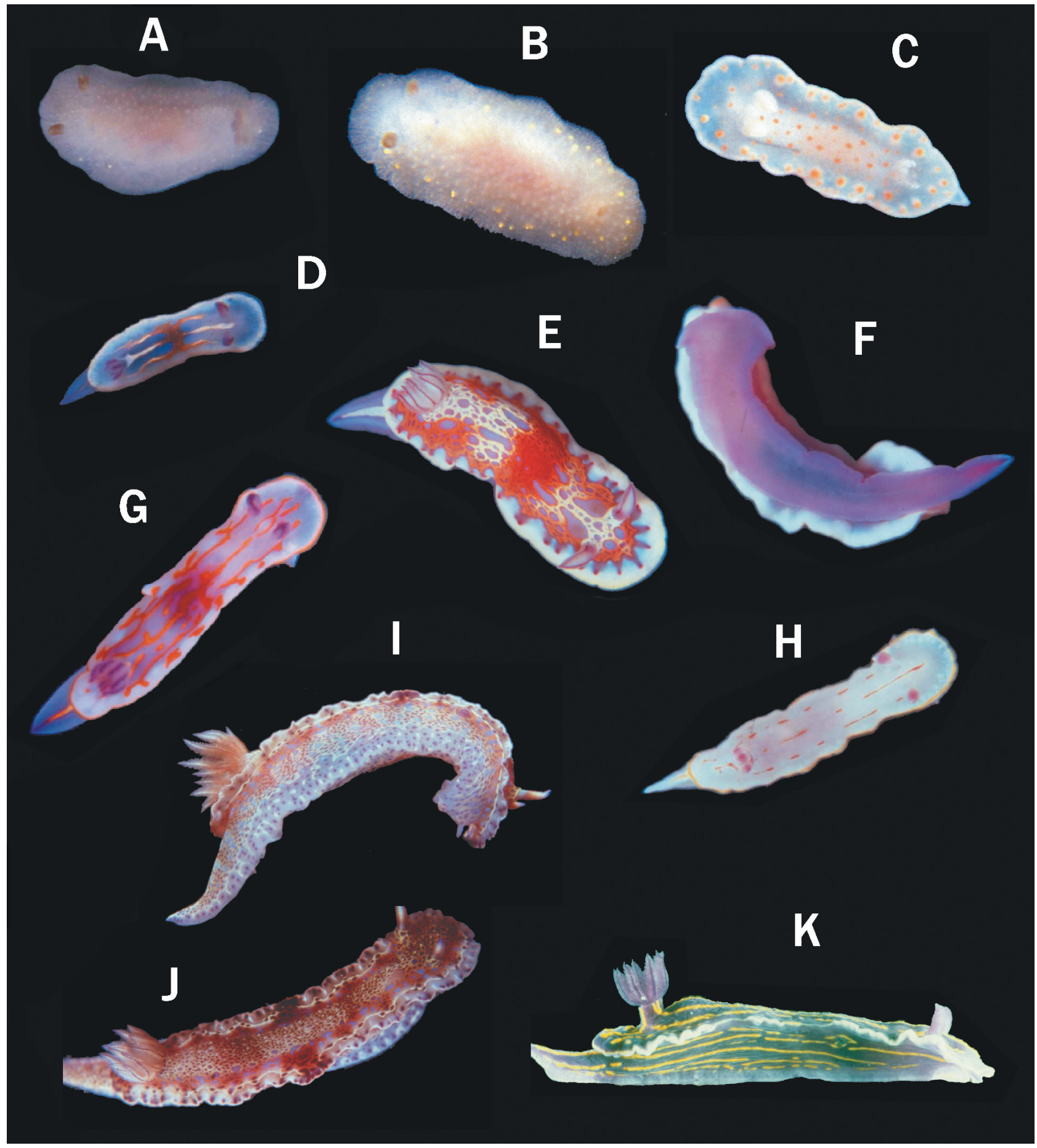

FIG 1. - A and B, Cadlina rumia; C, Tyrinna evelinae; D, Chromodoris binza; E and F, Chromodoris clenchi; G, Chromodoris neona; H, Chromodoris paulomarcioi $\mathrm{n}$. sp.; I and J, Hypselodoris marci; K, Hypselodoris lajensis.

There are few recent studies on opisthobranchs from southern Brazil. The species of this study (like many others of the family Chromodorididae) are, or have long been, the cause of many confusions and discords within the scientific community. The publications of Ortea et al. $(1994,1996)$ have been very useful for clarifying a great number of doubts about these species. They give detailed anatomical descriptions of the jaw elements, radula and reproductive system. We therefore provide illustrations of those animals that show some variations in comparison with the previous works, or additional information that may help to complete the knowledge of these species. 


\section{MATERIAL AND M,ETHODS}

Field samplings were carried out from 1993 to 2004 in order to increase knowledge of Brazilian opisthobranchs and their distribution in Brazilian waters. Numerous opisthobranch species were found, of which eight belonged to the family Chromodorididae. The sampling areas were located in Rio de Janeiro (Buzios and Cabo Frio) (between $22^{\circ} 44^{\prime}$ 'S, $41^{\circ} 57^{\prime} \mathrm{W}$ and $22^{\circ} 58^{\prime}$ 'S, $42^{\circ} 2^{\prime}$ 'W), São Paulo (Ilhabela and Laje de Santos) (between $23^{\circ} \mathrm{S}, 45^{\prime} \mathrm{W}$ and $24^{\circ} \mathrm{S}, 46^{\prime} \mathrm{W}$ ) and Fernando de Noronha Archipelago (Ilha Rata) (between $3^{\circ} 48^{\prime} \mathrm{S}, 32^{\circ} 24^{\prime} \mathrm{W}$ and $3^{\circ} 49^{\prime} \mathrm{S}, 32^{\circ} 22^{\prime} \mathrm{W}$ ). The specimens from Buzios were collected intertidally in shallow water, and the rest subtidally using SCUBA. The depths were 6-10 $\mathrm{m}$ at Cabo Frio and Fernando de Noronha, $1 \mathrm{~m}$ at Ilhabela, and 18-25 m at Laje de Santos. In the laboratory, photographs of live specimens were taken before they were anaesthetised. The animals were frozen prior to fixation in 5\% formalin and seawater, and were kept at 0 degrees $\mathrm{C}$ for 12-24 hours. They were then transferred to $70 \%$ ethanol.

Some specimens of Hypselodoris lajensis belonging to the Museo de Zoologia de la Universidad de São Paulo were examined. Six specimens collected in Laje de Santos and Cabo Frio were studied externally; one of them was dissected and its anatomical features were compared with those of our animals.

\section{RESULTS}

Cadlina rumia Er. Marcus, 1955

(Figs. 1A, B, 2, 3)

Material examined. (length in living animals): 2 specimens of length 5 and $7 \mathrm{~mm}$, Praia dos Ossos (Buzios, Rio de Janeiro), intertidal $(03 / 07 / 99) ; 3$ specimens of length $11.3,9.5$ and $9 \mathrm{~mm}$, Manguinhos (Buzios, Rio de Janeiro), intertidal (23/06/00); 1 specimen of length $6 \mathrm{~mm}$, Praia dos Ossos (Buzios, Rio de Janeiro), intertidal $(24 / 06 / 00) ; 1$ specimen of length $6 \mathrm{~mm}$, Praia dos Ossos (Buzios, Rio de Janeiro), intertidal (25/06/00).

External morphology. Oval shaped body and whitish ground colour; dorsum covered by rounded and small tubercles and spicules are visible through the mantle. Median part of dorsum is brown, due to the visceral mass, which can be seen slightly by transparency through the notum. Rhinophores are white with 4-5 brown lamellae. Variable number of yellow spots (Figs. 1A, B) around the mantle (5-14

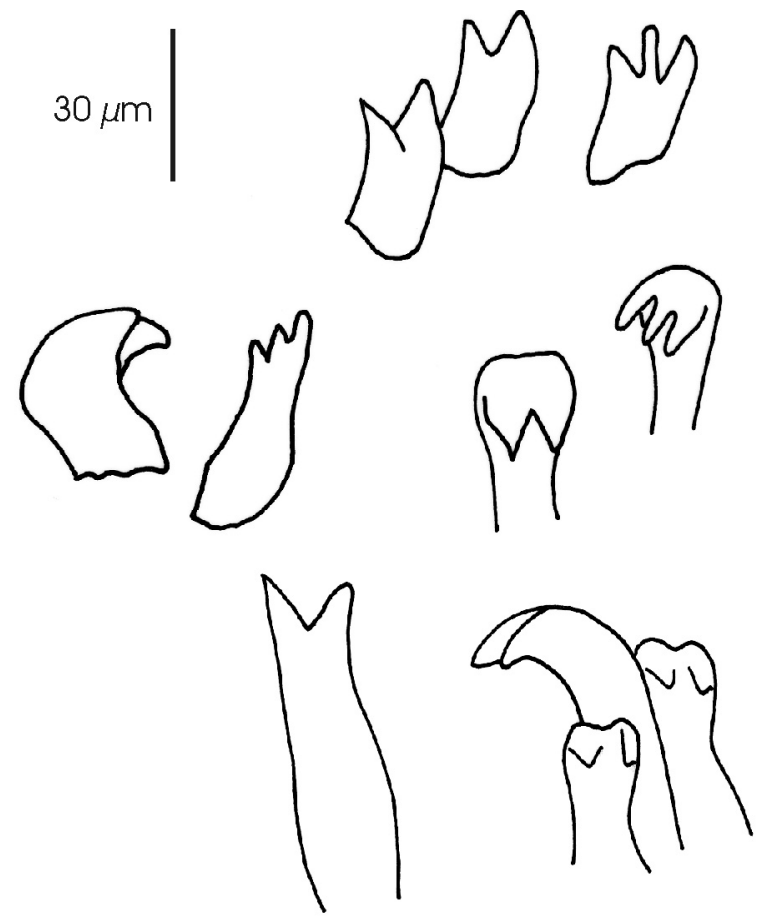

FIG. 2. - Cadlina rumia. Jaw elements.

on each side). There are 4-6 whitish or pale brown unipinnated gills. The hyponotum and the foot sole are white ventrally.

Internal anatomy. The jaw elements have two or three curved cusps (Fig. 2). The radular formula is $50 \times 12.1 .12$ and $67 \times 25.1 .25$ in two specimens of 6 and $11.3 \mathrm{~mm}$, respectively. The rachidian tooth showed 6 similar sized curved denticles, and the innermost lateral teeth are broad and have a median cusp with denticles on each side (Fig. 3A, B). The remaining teeth have a longer cusp and 5-6 denticles on the external side (Fig. 3C); the outermost teeth are smaller, and have a shorter cusp and denticles (Fig. 3D).

Remarks. Marcus (1955) described C. rumia as a white semitransparent animal, with brown rhinophores, yellowish unipinnated gills (pale brown in our animals) and 12-20 yellow spots surrounding the mantle. Just like Marcus, we observed that this number is variable (11 to 24 spots on the dorsum) and independent of animal size; some animals have a few spots (three or four on dorsum). The jaw elements have two cusps although there may be three or four at times.

The species $C$. laevis Linnaeus, 1767 is similar to C. rumia. It has jaw elements with two cusps, some- 

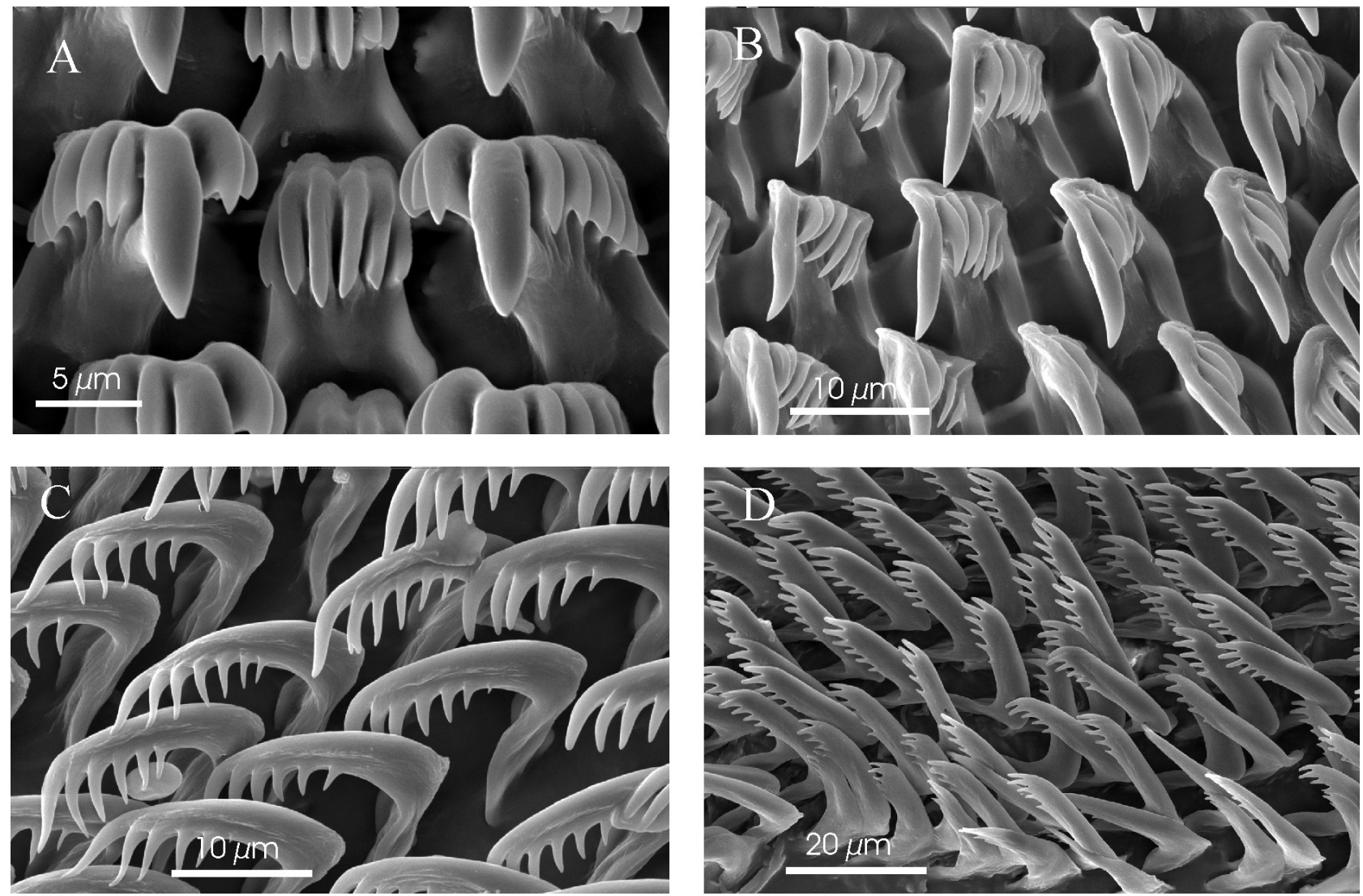

FIG. 3. - Cadlina rumia. A, rachidian and innermost lateral tooth on each side; B, innermost lateral teeth; C, lateral teeth; D, outermost lateral teeth.

times 3-4, and similar radular teeth, though the gills are unipinnated in $C$. rumia, whereas $C$. laevis has tripinnated gills (Marcus, 1955). García-Gómez (2002) described $C$. laevis as a whitish species with small yellow spots on the mantle, but in contrast to C. rumia, this species has yellow spots on the rim of the rhinophore sheath, on the mantle edge and on the gills. Thompson and Brown (1984) stated that $C$. laevis could vary in colour from the usual yellow spots on the mantle to the rare full yellow body. These variations caused enormous confusion in the taxonomy of Cadlina, but all specimens studied by us had spots on the mantle edge, the rhinophore sheath and the gills. Cadlina modesta MacFarland, 1966 is creamy in colour with 16-20 yellow spots on the dorsum and there are anatomical differences too with $C$. rumia, because it only has bifid jaw elements and the rachidian tooth of the radula has two cusps separated by a median groove.

Distribution. São Sebastião Island, Brazil (Marcus, 1955), Florida (Marcus, 1977), Jamaica (Thompson, 1980). Rios (1994) recorded this species from Curaçao, S. Martin, Puerto Rico and
Ubatuba, toward the south of Brazil. The present paper gives new records from Praia dos Ossos and Manguinhos, in Buzios (Rio de Janeiro).

Tyrinna evelinae (Er. Marcus, 1958)

(Fig. 1C)

Cadlina evelinae Er. Marcus, 1958, pp. 18-21, Figs. 28-33.

Material examined. (Length in living animals): 3 specimens of length 8, 7.5 and $3 \mathrm{~mm}$, Praia dos Ossos (Buzios, Rio de Janeiro), intertidal (03/07/99); 1 specimen of length $7.5 \mathrm{~mm}$, Armaçao (Buzios, Rio de Janeiro), intertidal (22/06/00); 5 specimens of length 12, 9.5, 5.5, 5 and $3.5 \mathrm{~mm}$, Manguinhos (Buzios, Rio de Janeiro), intertidal (23/06/00); 1 specimen of length $9 \mathrm{~mm}$, Praia dos Ossos (Buzios, Rio de Janeiro), intertidal (24/06/00); 1 specimen of length $7 \mathrm{~mm}$, Praia dos Ossos (Buzios, Rio de Janeiro), intertidal $(24 / 06 / 00)$.

External morphology. Elongated white translucent body; mantle edge and foot have a thin white line (Fig. 1C). There are numerous dark orange-yellow spots over the dorsum; some specimens have bigger and more numerous spots on the mantle edges. There are five white bipinnated gills, the posterior ones smaller than the anterior ones. Rhinophores are white with 8-9 lamellae. 
Remarks. Marcus (1958) described this species and included it into the genus Cadlina. Thompson (1980) found some opisthobranchs of this species in Jamaica, but his specimens were different from those of Marcus (1958) and Collier and Farmer (1964) because the oral tentacles were not coiled and they were finger-shaped. Rudman (1984) assigned this species to the genus Tyrinna because he felt that the coiled oral tentacles were characteristic for Tyrinna.

This species was studied in detail by Schrödl y Millen (2001), who gave illustrations of radula and reproductive system. These anatomical characteristics coincide with those of our specimens.

Tyrinna nobilis Bergh, 1898 is similar to T. evelinae but the latter has yellow or reddish orange marks scattered along the dorsum, whereas T. nobilis has only orange or red marks on the mantle edge.

Distribution. This species was captured in Ilhabela and Guarujá, near Santos, in the Brazilian State of São Paulo (Marcus, 1958), Baja California (Collier and Farmer, 1964), Gulf of California (Marcus and Marcus, 1967a), Puerto Rico (Marcus,
1977), Ghana (Edmunds, 1981 and 1982) and Peru (Schrödl and Millen, 2001). This paper records species from Praia dos Ossos, Armaçao and Manguinhos (located in Buzios, Rio de Janeiro).

Chromodoris binza Ev. Marcus and Er. Marcus, 1963 (Figs. 1D, 4)

Material examined. (Length in living animals): 1 specimen of length $5 \mathrm{~mm}$, Praia dos Ossos (Buzios, Rio de Janeiro), intertidal (03/07/99); 1 specimen of length $6 \mathrm{~mm}$. Praia dos Ossos (Buzios, Rio de Janeiro), intertidal (25/06/00).

External morphology. Body with pale blue ground colour, deeper on the median part of dorsum; the edge has a very thin red-orange line and there is a broad white-cream band within it (Fig. 1D). There are three longitudinal lines, one median line and two lateral ones, with pale yellow ends and orange areas on the median part of the dorsum. These lines join in the middle where they are deep orange. Small rays arise from the lateral lines and the central line divides into two rays in front of the gills. There are five unipinnated violet pinkish gills, with violet rachis. The posterior gills are paler. The rhinophores
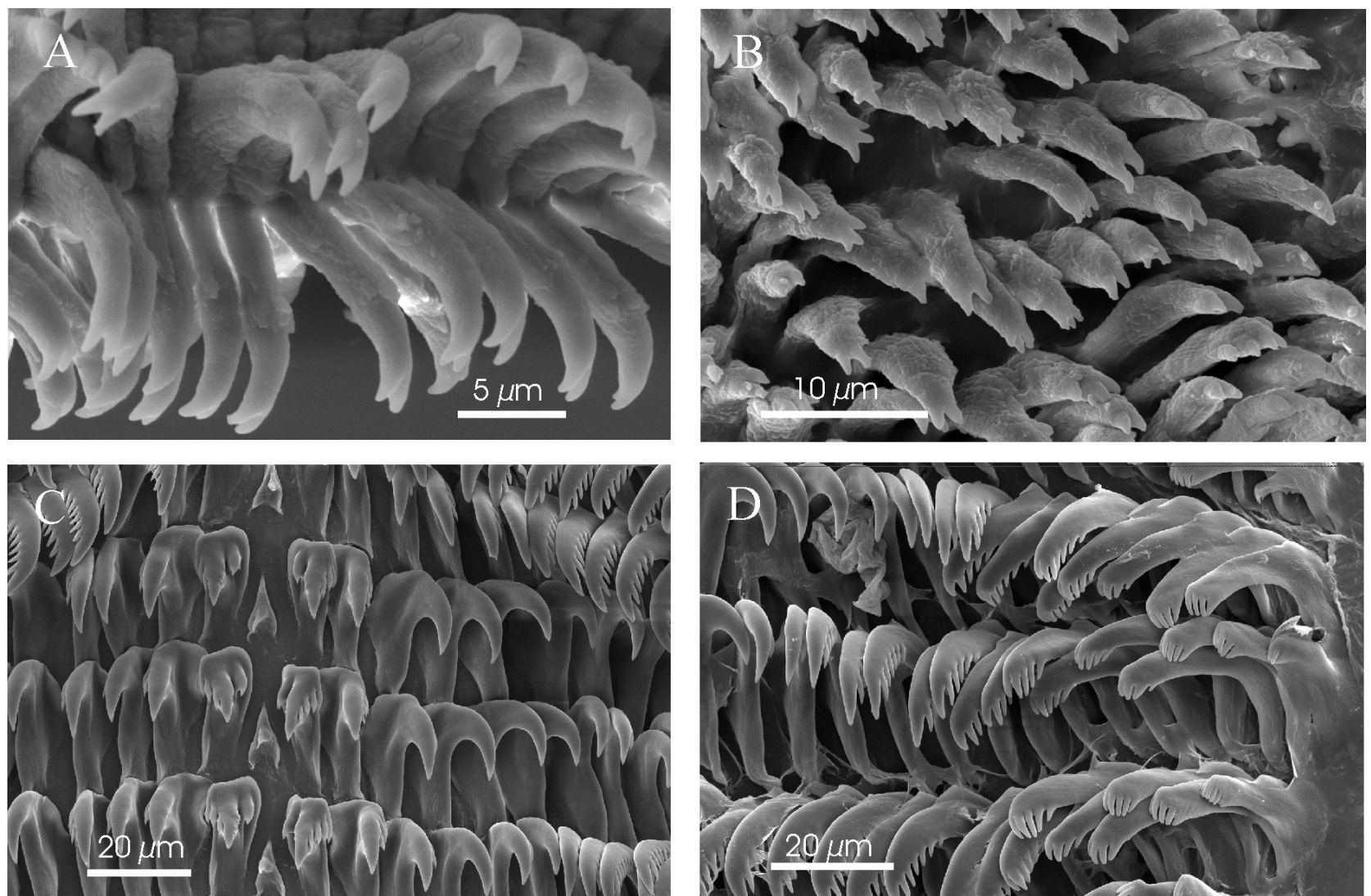

FIG. 4. - Chromodoris binza. A, jaw elements with two tips. B, jaw elements with two or more tips. C, rachidian tooth and innermost lateral teeth on each side. D, outermost lateral teeth. 
are violet and they have an anterior dark violet median line. The foot is pale violet to blue and there is a median darker violet band over it with small yellow marks on the median part of the band.

Internal anatomy. The jaw elements are 9-16 $\mu \mathrm{m}$ in length. They have two cusps (Fig. 4A) although sometimes the elements are provided by three or four cusps (Fig. 4B). The radular formula is $27 \mathrm{X}$ 22.1.22 for the $5 \mathrm{~mm}$ specimen and $28 \mathrm{X} 23.1 .23$ for the $6 \mathrm{~mm}$ specimen. The rachidian tooth is triangular-shaped with a little cusp, although one specimen has a tooth with a bifid cusp; the innermost lateral tooth has two cusps, a small inner cusp and an outer cusp with denticles on each side (Fig. 4C). The outer lateral teeth have about four denticles only on the outer side. The cusp becomes progressively longer from the sixth tooth. These teeth has about six denticles; the outermost teeth have a short cusp and 4-5 denticles (Fig. 4D).

Remarks. The specimens studied were small and their dorsal pattern was simple; in bigger specimens, the pattern was more complex and showed greater variation. This is normal in Chromodorididae, which is why the external morphology of these specimens differed from the colour pattern described for the species. Even so, our specimens have some characteristics in common with those of Marcus and Marcus (1963); the mantle is blue, the dorsal bands are yellowish to orange, the gills are unipinnated and the rhinophores have a dark line. There are some variations in the radula because, in contrast to our specimens, those examined by Marcus and Marcus (1963) lack a cusp in the rachidian tooth and the innermost lateral tooth has a cusp with one internal and four external denticles.

Ortea et al. (1994) state that the presence of cream colour on the dorsum is a very distinctive characteristic in this species group. These authors illustrated internal parts of Chromodoris binza, such as the reproductive system and radula. They stated that $C$. binza has a rachidian tooth with a slightly marked cusp and the innermost lateral tooth (just like in our specimens) has two cusps with denticles.

Chromodoris britoi Ortea y Pérez, 1983 has yellow to orange lines but, unlike $C$. binza, the dorsum is pinkish. The juveniles have three yellow lines on the dorsum; the unipinnated gills are surrounded by yellow pigment and the rachis is violet; the rhinophores are pink-violet with darker anterior part. Valdés (pers. comm.) doubt whether Chromodoris binza from the Caribbean Sea and Chromodoris britoi from the Mediterranean Sea and eastern Atlantic are different species. Ortea et al. (1994) consider that these species are different because $C$. britoi have no red pigments (although specimens with deep orange lines from Israel have been described) and the main difference is the shape of the radular teeth, although the radula has many similarities to those of $C$. britoi.

Distribution. Curaçao (Marcus and Marcus, 1963), Brazil, São Paulo near Ubatuba (Marcus, 1957), Florida (Marcus and Marcus, 1967b), Colombia (Marcus, 1976; Bandel, 1976), Jamaica (Thompson, 1980), Cuba (Ortea et al., 1994), Praia dos Ossos in Cabo Buzios, Rio de Janeiro (present paper).

Chromodoris clenchi (Russell, 1935)

(Figs. 1E, F)

Glossodoris clenchi Russell, 1935, 49: 59, Fig. 5.

Glossodoris neona Marcus, 1955: Marcus, (1957), 43: 429-420, Figs. 70-72.

Chromodoris neona (Marcus, 1955): Marcus and Marcus, (1967b), 6: 51-53, Figs. 58, 58a, pl. 1(9).

Material examined. (Length in living animals): 2 specimens of length 19 and $21 \mathrm{~mm}$, Buraco do Inferno (Fernando de Noronha Archipelago), depth $10 \mathrm{~m}$ (07/07/99); 1 specimen of length $23 \mathrm{~mm}$, Buraco do Inferno (Fernando de Noronha Archipelago), depth $7 \mathrm{~m}$ (08/07/99).

External morphology. Elongated body with pale yellow mantle edge and white broad band around it (Fig. 1E). There is an irregular orange band within it. The withe and orange band are separated by a red line which arises as a triangular reddish blotch running to the edge and has a deep red end. On the central area there are two pale yellow to cream areas separated by a deep orange zone; there is an anterior area which includes the rhinophore sheaths and a posterior area located in front of the gills. The orange zones of the dorsum have numerous small blue spots; the cream areas have small and bigger blue spots surrounded by a red line. The sharp-pointed rhinophores are whitish with 18 lamellae; there are three violet lines running from the tip to the stalk, one anterior line and two posterior lateral ones. The whitish gills have violet rachis; there are 13 unipinnated gills and two posterior ones have three branches each. The tail is blue-violet with a yellow median longitudinal mark which narrows to the tip and is surrounded by a red line. Ventrally 
(Fig. 1F), the mantle edge is similar in colour to the dorsum, the hyponotum is white and the foot sole is violet.

Remarks. The characteristics of $C$. clenchi were described in detail by Ortea et al. (1994), who provided illustrations of the radular teeth and reproductive system. According to these authors, this species is easily recognised from the original description of Russell (1935), which states that the basic colour is red (although our animals are orange), with two pale cream areas and some blue spots surrounded by red, and that the rhinophores are sharply pointed and pale with three dark lines. These features are the same as those in our specimens, but Ortea et al. (1994) consider that the foot is violet with small posterior spots which are not present in our specimens. In their opinion, one distinctive feature to separate $C$. clenchi from similar species is the presence of a cream colour on the dorsum, because $C$. clenchi presents it. For this reason, they say that the specimen called $C$. neona in Marcus and Marcus (1967a) and illustrated in Figures 58, 58A and pl. I (9) is in fact $C$. clenchi. The species $C$. binza has a cream colour on the dorsum, but its dorsal pattern is different.

Distribution: Bermuda (Russell, 1935), São Paulo, near Ubatuba (Marcus, 1957), Florida (Marcus and Marcus, 1967a), Jamaica (Thompson, 1980), Barbados (Edmunds and Just, 1985), Cuba (Ortea et al., 1994), Puerto Rico (Marcus, 1977). The species is recorded for the first time from Fernando de Noronha Archipelago (Brazil) in this paper.

Chromodoris neona (Er. Marcus, 1955) (Figs. 1G, 5)

Glossodoris neona Marcus, 1955: 20: 124-127, Figs. 90-101.

Material examined. (Length in living animals): 1 specimen of length $19 \mathrm{~mm}$, near Ilha das Cabras (Ilhabela, São Paulo), depth 1 m $(24 / 05 / 04)$.

External morphology. Elongated body with a narrow orange band around the mantle; dorsally pale blue to violet, slightly darker on the central area and whitish on the lateral margins (Fig. 1G). There are some irregular lines and deep orange spots which extend from the anterior area to behind the gills. Furthermore, there are six blue elongated spots on each body side. The rhinophores are violet with

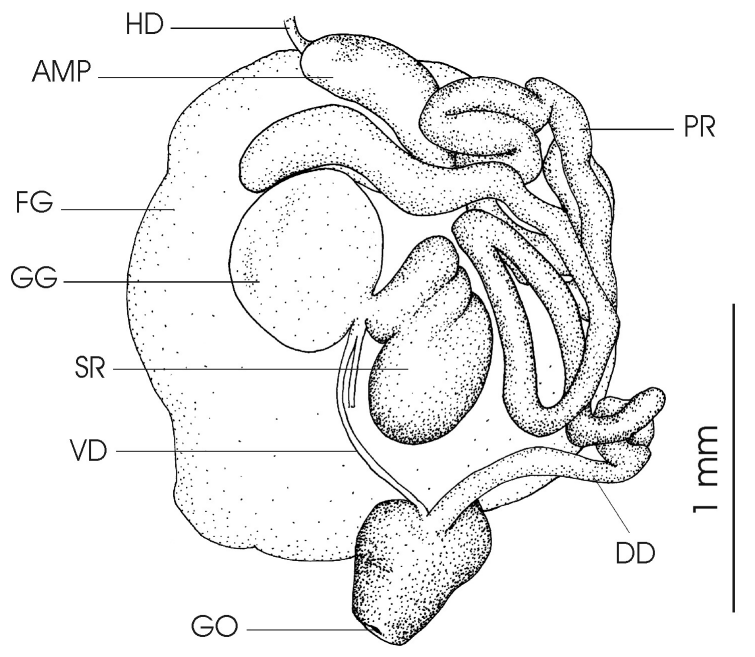

FIG. 5. - Chromodoris neona. Reproductive system. AMP, ampulla; DD, deferens duct; FG, female gland; GG, gametolytic gland; $\mathrm{GO}$, genital opening; HD, hermaphrodite duct; PR, prostate; SR, seminal receptacle; $\mathrm{VD}$, vaginal duct.

three longitudinal deep violet bands, one anterior and two posterior. There are nine unipinnated gills, with translucent branched and violet rachis. The tail is blue-violet, darker on the tip, with a median orange band which is broad and pale in front and is narrow posteriorly; it is followed by a dark violet line that runs though to the apex tail. The animal is white ventrally.

Internal anatomy. The reproductive system (Fig. 5) has a kidney-shaped ampulla, which leads to the hermaphroditic duct; the ampulla is joined to a broad, long and coiled prostate. The vaginal duct is very narrow and joins at the union between the gametolytic gland and the seminal receptacle. Another shorter duct arises from this zone and goes into the female gland, which is very long. The gametolytic gland is large and spherical, and the seminal receptacle is large and has one rounded part and one irregular part.

Remarks. Chromodoris neona has a light blue colour, a red mantle edge, red lines and marks (deep orange in our specimen) that form an irregular pattern with six blue areas near it (Marcus, 1955). Ortea et al. (1994) think that $C$. neona is characterised by a lack of cream colour in its body, as against similar species such as $C$. britoi and C. binza. Chromodoris clenchi also has a cream colour on the dorsum, and its dorsal pattern differs from that of $C$. neona. These authors indicate the presence of a larger seminal receptacle than the gametolytic gland. The stud- 


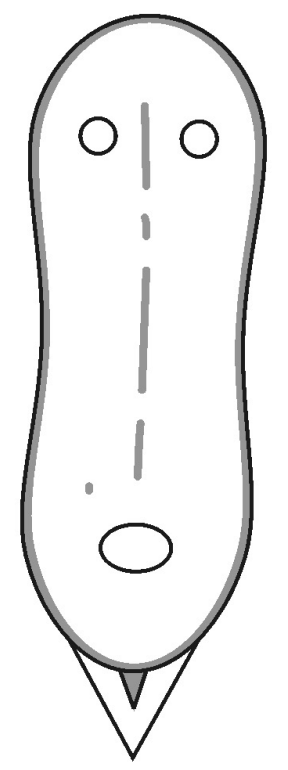

$4 \mathrm{~mm}$

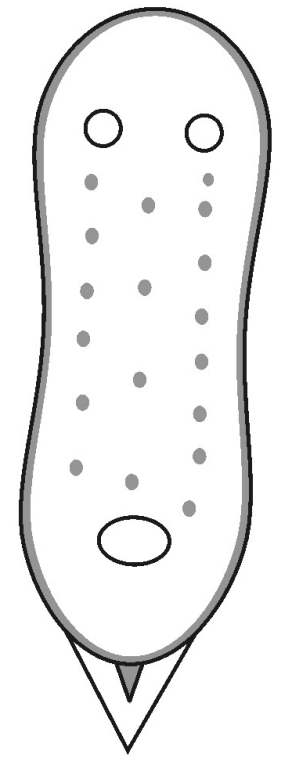

$4 \mathrm{~mm}$

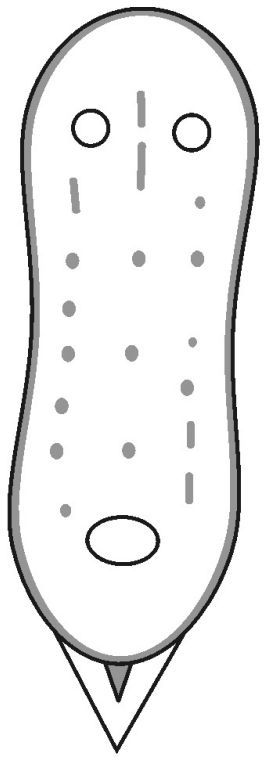

$11 \mathrm{~mm}$

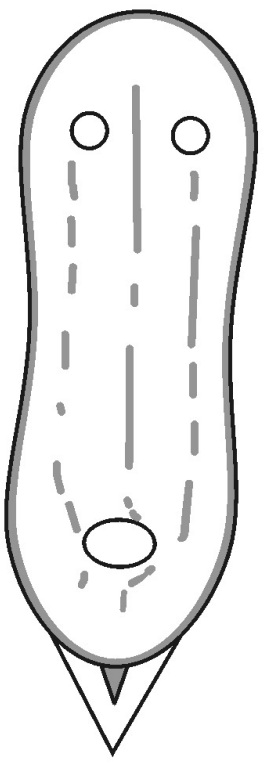

$12 \mathrm{~mm}$

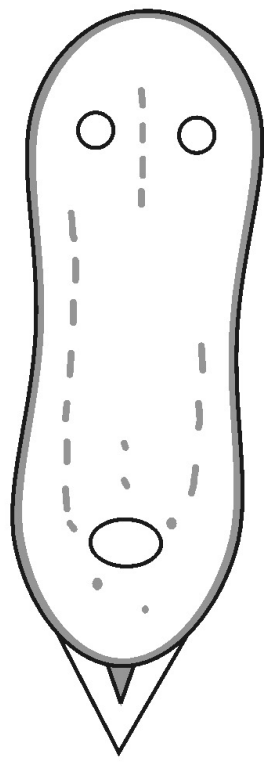

$15.5 \mathrm{~mm}$

FIG. 6. - Chromodoris paulomarcioi n.sp. Some specimens with different sizes showing the dorsal pattern.

ied specimen has a seminal receptacle that is as big as the gametolytic gland. This is the demonstration of the variability in the same species, but this size is a feature that allows it to be distinguished from $C$. binza, $C$. clenchi and $C$. neona, because these species have a seminal receptacle smaller than the gametolytic gland.

Distribution. São Sebastião and Ubatuba, Brazil (Marcus, 1955), Florida (Marcus and Marcus, 1967a), Panama (Marcus and Marcus, 1967c), Colombia (Marcus, 1977), Cabo Frio, Rio de Janeiro (Rios, 1994), near Ilha das Cabras, Ilhabela, São Paulo (present paper).

Chromodoris paulomarcioi $\mathrm{n}$. sp.

(Figs. 1H, 6, 7, 8)

Material examined. (Length in living animals): Holotype, one specimen of $7 \mathrm{~mm}$ in length, intertidal, collected at Praia dos Ossos, Buzios, Rio de Janeiro (03/07/99), deposited at the Museo de Zoologia de la Universidad de São Paulo, in São Paulo, Brazil, with the registration number MZUSP 52191. Paratypes, two specimens, 6.5 and $5 \mathrm{~mm}$ in length, intertidal, collected at the same station (03/07/99), deposited in the Museo de Zoologia de la Universidad de São Paulo with the registration number MZUSP 64149, and two specimens, 6.5 and $5 \mathrm{~mm}$ in length, intertidal, collected at the same station (03/07/99), deposited in the Museo Nacional de Ciencias Naturales de Madrid (Spain) with the registration number MNCN $15.05 / 46977$

Other material. 1 specimen of length $11 \mathrm{~mm}$, Praia dos Ossos (Buzios, Rio de Janeiro), intertidal (27/06/99); 1 specimen of length $4 \mathrm{~mm}$, Armaçao (Buzios, Rio de Janeiro), intertidal (30/06/99); 4 specimens of length $12,7.5,7.2$ and $4.75 \mathrm{~mm}$, Praia dos Ossos (Buzios, Rio de Janeiro), intertidal (03/07/99); 1 specimen of length $15.5 \mathrm{~mm}$, Armaçao (Buzios, Rio de Janeiro), intertidal (03/07/99); 1 specimen of length $4 \mathrm{~mm}$, Armaçao (Buzios, Rio de Janeiro), intertidal $(22 / 06 / 00)$.

Etymology. The name paulomarcioi was chosen in honour of Dr. Paulo Marcio Costa, a Brazilian malacologist and friend.

External morphology. Elongated body with a white dorsum and a pale purple central area. Thin white line around the mantle edge; fine orange band within it and inner white glands arranged around the margins. Three broken orange lines on the dorsum (Fig. 1H) or three rows of separated spots, especially in juveniles, which have more separated spots. Some young specimens can have one median line between the rhinophores (Fig. 6). Variation of the dorsal pattern of some specimens of different size is showed in Fig. 6. There is a longitudinal median orange line on the tail. The rhinophores are purple with a white base and tip and there are 14 lamellae in a specimen of length $12 \mathrm{~mm}$. There are about seven gills, which are contractile but they do not retract completely inside the gill pocket; the three or four anterior gills are purple and the posterior gills are smaller and translucent white. Over the translucent white tail there is a median tenuous opaque white line. Ventrally, the foot is white. One young specimen of length $4 \mathrm{~mm}$ had a translucent white 
mantle, especially on the margins; the edge is yellow and has a broken reddish line on the median part; there are 4-5 reddish spots surrounding the gills, which have three white branches. The white rhinophores have 6-7 lamellae. The yellow mantle edge is visible ventrally and the foot is white.

Internal anatomy: Jaw elements have a bifid curved cusp (Fig. 7A), each of length $15 \mu \mathrm{m}$. The radular formula of a $12 \mathrm{~mm}$ specimen is $25 \mathrm{X} 20.0$. 20. There is no rachidian tooth and the innermost lateral tooth has a broad base, one or two inner denticles and 2-4 denticles on the outer side (Fig. 7B). The next lateral teeth have up to nine denticles (Fig. 7C), and the most external lateral teeth are elongated and have 4-6 denticles (Fig. 7D).

Reproductive system (Fig. 8E): The hermaphroditic duct goes to an ovate ampulla which is inserted in the female gland and bifurcates giving male and female ducts; the male duct widens towards the prostate; the prostate is long and coiled, slightly narrow and followed by the post-prostatic deferent duct, which is thicker than the prostate and goes to the genital opening. There is a very fine vaginal duct near it, which is inserted between the elongated seminal receptacle and the spherical gametolytic gland, which has a fine wall.

Remarks. This species is very similar to the "Chromodoris splendida colour group" proposed by Rudman (1983), which have a white mantle and red marks; sometimes the notum can be blue or pink and most species have a yellow to orange edge colour. Ten species of this colour group are endemic for SE Australia (Rudman, 1991). External features of Chromodoris splendida (Angas, 1864) are similar to those of Chromodoris paulomarcioi n. sp. because its mantle is white with a yellow edge and red rhinophores, but with some distinctive characteristics: the dorsum has large red patches instead of three lines or three rows of small orange spots, the rhinophores have lamellae with white edge and the gills are white with a red line (Rudman, 1983). Furthermore, the tail has one or two red spots instead of a line.

Chromodoris daphne (Angas, 1864) is different from $C$. paulomarcioi $\mathrm{n}$. sp. because, according to Rudman (1983), the mantle is surrounded by a thin
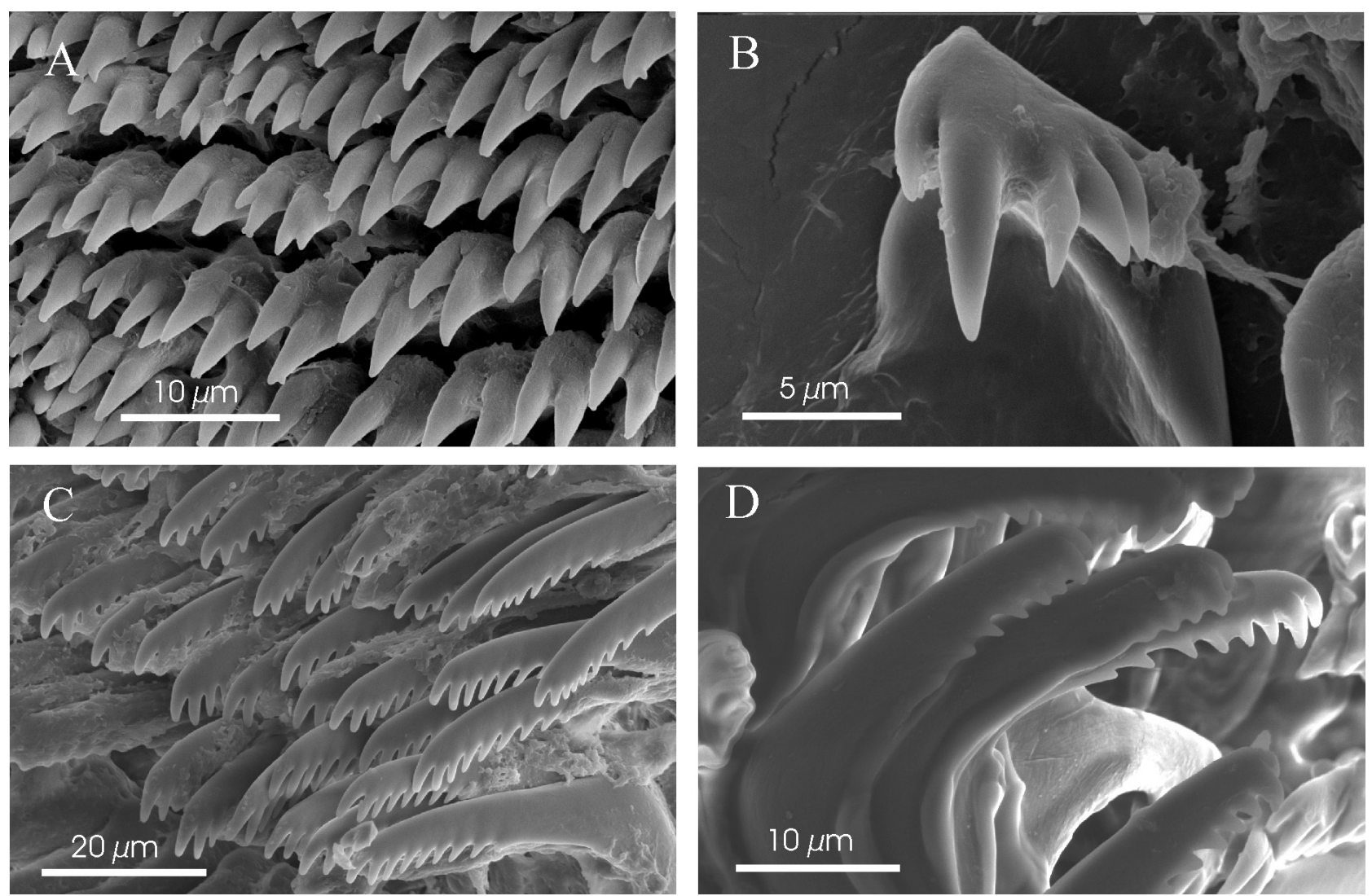

FIG. 7. - Chromodoris paulomarcioi n.sp. A, jaw elements; B. innermost lateral tooth; C, lateral teeth; D, outermost lateral teeth. 


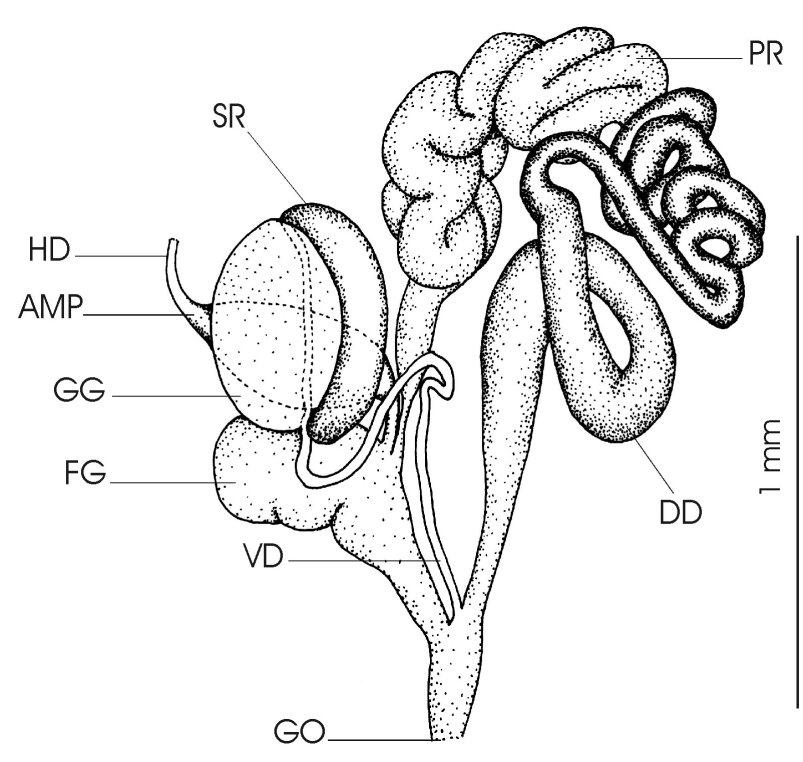

FIG. 8. - Chromodoris paulomarcioi $\mathrm{n}$.sp. Reproductive system.

red line and there is a yellow line within it. Scattered on the dorsum are small red marks which are not aligned in longitudinal rows. There is no longitudinal stripe over the tail and the gills are red with white bases, while C. paulomarcioi n. sp. have completely reddish or pink anterior branchia.

Chromodoris hunterae Rudman, 1983 has similar coloration, with a white mantle, a submarginal yellow band and red marks on the dorsum, but in contrast to our specimens the gills and rhinophores are white (Rudman, 1983).

Chromodoris tasmaniensis Bergh, 1905 shows three distinct colour forms, but the general features are a white or creamy body with red to orange marks on the mantle and sometimes on the foot (Rudman, 1983). Although these characteristics are present in our specimens, C. tasmaniensis has whitish rhinophores and gills instead of purple or reddish ones and the rhinophorical and gill sheaths are surrounded by red or orange colour.

Externally, Noumea haliclona (Burn, 1957) is very similar to $C$. paulomarcioi. Its features are compiled by Rudman (1983), who saw that its ground coloration is white to pink, with numerous red or orange marks, and that there is a yelloworange band around the mantle. However, this species differs from $C$. paulomarcioi because the pink coloration is not concentrated on the median part of dorsum but is evenly distributed, and the marks are not aligned or fused in a line. The rhinophores and gills are pink, but an invariable feature in Noumea haliclona (including the younger specimens) is the presence of a reddish mark on the anterior side of rhinophores, just below the terminal papillae (Rudman, Opus cit.). Chromodoris paulomarcioi lacks this mark.

TABLE 1. - Comparison between Chromodoris paulomarcioi n. sp. and Chromodoris grahami.

\begin{tabular}{|c|c|c|c|}
\hline & Chromodoris paulomarcioi $\mathrm{n}$. sp. & $\begin{array}{l}\text { Chromodoris grahami } \\
\text { (based on Thompson, 1980) }\end{array}$ & $\begin{array}{l}\text { Chromodoris grahami } \\
\text { (based on Bertsch, 1988) }\end{array}$ \\
\hline Dorsum ground colour & White with pink central area & Salmon-pink & $\begin{array}{l}\text { Specimens from St. Vicente and Puerto } \\
\text { Rico salmon-pink; specimens from } \\
\text { Panama pinkish red. }\end{array}$ \\
\hline $\begin{array}{l}\text { Arrangement of lines of } \\
\text { spots on the dorsum }\end{array}$ & $\begin{array}{l}\text { Three broken lines or three } \\
\text { rows of orange coloured spots }\end{array}$ & $\begin{array}{l}\text { Three longitudinal rows of red } \\
\text { marks }\end{array}$ & $\begin{array}{l}\text { Specimens from St. Vicente and Puerto } \\
\text { Rico: red spots arranged in three longi } \\
\text { tudinal rows. Specimens from Panama: } \\
\text { scattered irregularly. }\end{array}$ \\
\hline Tail & An orange longitudinal line & $\begin{array}{l}\text { Yellow and white longitudinal } \\
\text { lines on the tail and dorsal } \\
\text { edge of tail. }\end{array}$ & \\
\hline Mantle edge coloration & A thin orange line. & Yellow and white lines. & $\begin{array}{l}\text { Specimens from Puerto Rico and } \\
\text { Panama: a white band. Specimens from } \\
\text { St. Vicente: a yellow line, thin red line } \\
\text { within it and a white band }\end{array}$ \\
\hline Rhinophores & Purple with white tips and bases & $\begin{array}{l}\text { Red with white tip and } \\
\text { white speckles }\end{array}$ & Red-pinkish with whitish tips and edges \\
\hline Number of gills & Juveniles, 3 gills; adults, 7 gills. & 14 unipinnated gills & Not indicated \\
\hline Gills coloration & $\begin{array}{l}\text { Anterior gills purple; posterior } \\
\text { gills whitish }\end{array}$ & $\begin{array}{l}\text { Red rachis, pink leaflets and } \\
\text { white tips }\end{array}$ & Red pinkish \\
\hline Radular formula & $25 \times 20.0 .20$ (specimen $12 \mathrm{~mm})$ & $36 \times 23.0 .23$ (specimen $13 \mathrm{~mm})$ & 39 X 26-27. 0. 26-27 (specimen $8 \mathrm{~mm}$ ) \\
\hline Radular teeth & $\begin{array}{l}\text { Innermost lateral tooth with } 1 \\
\text { or } 2 \text { denticles on internal side and } \\
4-6 \text { on the outer side. Lateral } \\
\text { teeth elongated and provided } \\
\text { with } 4-6 \text { denticles }\end{array}$ & $\begin{array}{l}\text { Innermost lateral tooth with } \\
1 \text { internal denticle and } 4 \\
\text { external.The lateral teeth } \\
\text { are elongated with denticles }\end{array}$ & $\begin{array}{l}\text { Innermost lateral tooth with } \\
4-5 \text { external denticles. The lateral teeth } \\
\text { are more elongated with denticles }\end{array}$ \\
\hline
\end{tabular}


There is a very similar species called Chromodoris grahami Thompson, 1980, in the western Atlantic, which has a salmon pink dorsum and red marks that form three longitudinal rows; the mantle is yellow and white according to Thompson (1980). Bertsch (1988) found some colour variations in $C$. grahami from specimens collected in Puerto Rico, Panama and St. Vicente (Table 1). The rhinophores are red with white marks and the gills are pink with red rachis and a white tip (Thompson, 1980). The differences between the two species are listed in Table 1. The distinctive features of this species include the absence of longitudinal stripes on the dorsum (C. grahami has spots); the dorsum is salmon pink in C. grahami, whereas C. paulomarcioi has a white dorsum with a pinkish central part; the colour of the mantle edge of $C$. grahami (which can be variable between specimens from different locations) is different to that of our species, and the gills are red and pink with a white tip instead of purple anterior gills and posterior whitish gills. Internally they have similar radular teeth, but the radular formula is different because $C$. paulomarcioi has fewer rows. Thompson (1980) and Bertsch (1988) say that the lateral teeth are long and pectinate. Their drawings show denticles on the radular teeth but fewer than those of $C$. paulomarcioi. The reproductive system of $C$. grahami has never been studied, and we cannot compare it with the new species.

Distribution: This species has been collected from Buzios, Rio de Janeiro (Praia dos Ossos and Armaçao).

\section{Hypselodoris marci Ev. Marcus, 1970}

(Figs. 1I, J, 9)

Material examined. (Length in living animals): 1 specimen of length $38 \mathrm{~mm}$, Ilha de Cabo Frio (Arraial do Cabo, Rio de Janeiro), depth $6 \mathrm{~m}(28 / 06 / 99) ; 1$ specimen of length $52 \mathrm{~mm}$, Ilha de Cabo Frio (Arraial do Cabo, Rio de Janeiro), depth 6 m (29/06/99).

External morphology. The mantle edge is pale orange and there is a translucent area within it which has deep brown spots and a golden yellow band with brown spots (some marks run to the edge from this band); within it there is a wide orange-reddish band with sky blue spots. The median area of the dorsum is golden yellow with numerous brown spots which are more densely concentrated in two separate areas, located between the rhinophores and the gills (Fig.
1J). The rhinophoral sheaths are iridescent golden yellow with dark brown spots, and the rhinophores are pale yellow with a very dark brown band and indigo blue tip. Eyes are visible behind the rhinophores and are included in a translucent area. There are 12-15 gills, each of which can be further branched into two or three. Gills are pale yellow or reddish with yellow tips and violet rachis. On each side of body, the hyponotum has the same pattern as the dorsum (Fig. 1I). There is a translucent area near the edge and a yellow band with deep brown spots; an orange reddish band with brown and blue spots, and a yellow area with lots of small brown and sky blue spots follows it; yellow lines run to the underside, which is violet-blue with pale yellow and deep purple spots. The oral tentacles are blue. The tail is long and has a yellow network with brown spots on the margin and sky blue spots on the median part dorsally.

Internal anatomy: There are numerous jaw elements with one curved cusp (Fig. 7A). The radular formula of a specimen of length $38 \mathrm{~mm}$ is $55 \mathrm{X}$ 85.0 .85 , and that of a specimen of length $52 \mathrm{~mm}$ is $68 \times$ 106.0.106. Teeth are bifid (Figs. 7B, C) and lateral teeth have 3-5 denticles on the lower part of second cusp, which is slightly shorter than the other one (Fig. 7D). Outer lateral teeth have short and rounded cusps with an irregular edge and rounded denticles (Fig. 7E) and the marginal teeth are triangular in shape.

Remarks. The description of these specimens has similar features to that of Marcus (1970), but it is important to point out that her description is based on two preserved specimens. Ortea et al. (1996) studied two animals which had a white mantle edge with black marks and a fine orange line that runs externally, and the white band was broken in front of the rhinophores, on the median part of dorsum and behind the gills by an orange band with black spots. The dorsum in their specimens was orange with blue marks and black speckles, whereas the specimens examined by us have a yellow central dorsum with deep brown spots, an orange reddish band with brown and blue marks, and a yellow line within it with dark brown spots. Ortea et al. (1996) examined specimens with three denticles on the second cusp of the lateral teeth, but we studied specimens with four or five denticles, whereas Marcus (1970) shows a figure of a lateral tooth with five or six denticles. 

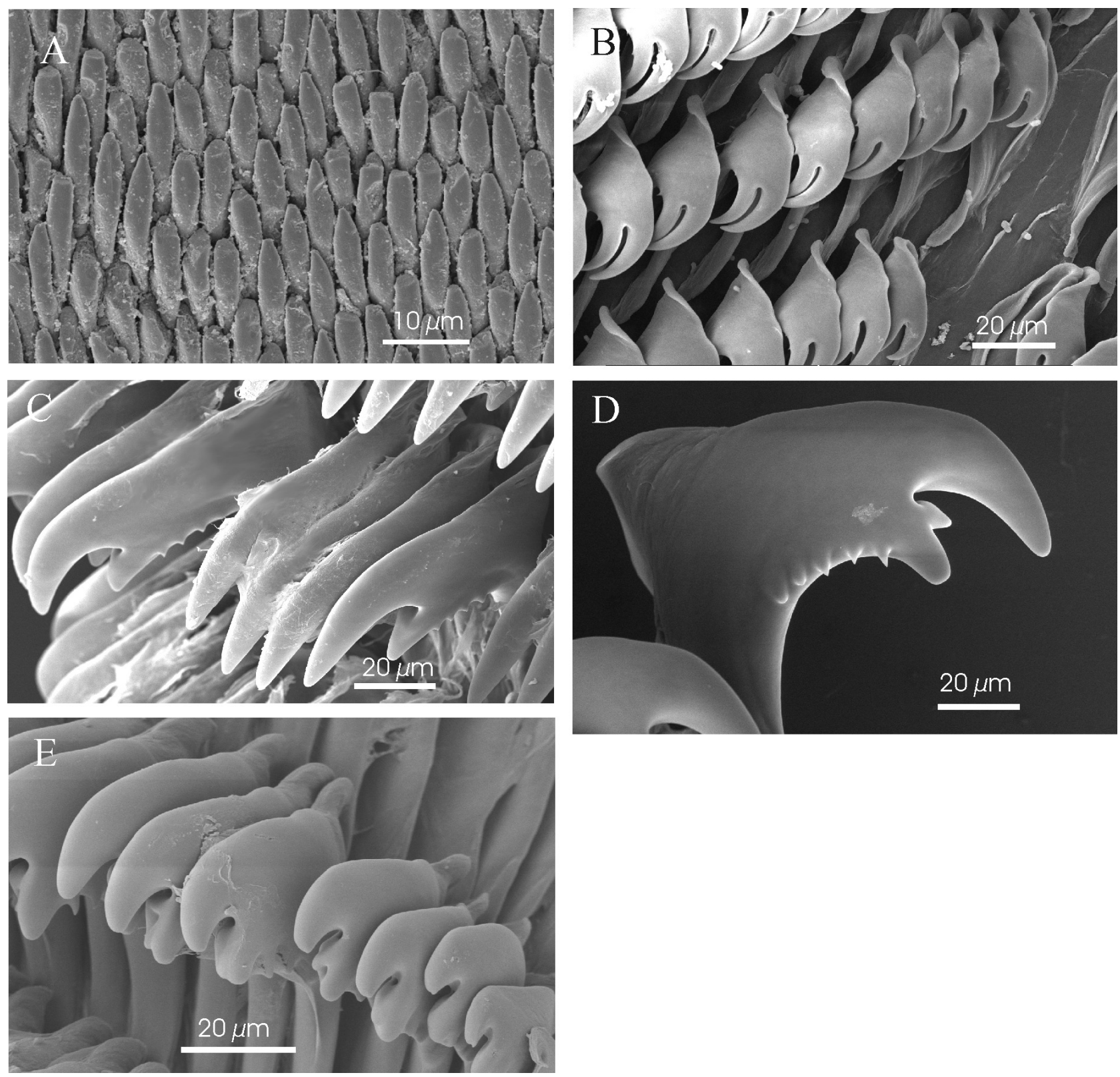

FIG. 9. - Hypselodoris marci. A, jaw elements. B, innermost lateral teeth. C, lateral teeth. D, lateral tooth. E, outermost lateral teeth.

Hypselodoris acriba has a fine orange line on the mantle edge and there is a thin yellow band with blackish flecks separating the central part from the margin (Marcus and Marcus, 1967a). The dorsum has blue spots which are bigger towards the edge. H. acriba differs from this species because the mantle edge has a wide unadorned band, whereas $H$. marci has a band with numerous deep brown spots; furthermore the median part of the dorsum of $H$. acriba has a network of yellow lines over the blue mantle, whereas $H$. marci has a yellow central part with numerous brown flecks and this part is surrounded by a wide reddish band with brown and blue marks. $H$. acriba and $H$. marci have similar radular teeth. Thompson (1980) described some specimens of $H$. marci collected in Jamaica, such as H. bayeri. This is another evidence of the confusion between the two species.

Distribution. Northern Brazil, Venezuelan Caribbean (Marcus, 1970), Jamaica (Thompson, 1980), Belize, Caiman Islands and Bay Islands (Humann, 1992), Mexico (Ortea et al., 1996). This is the first record from southern Brazil, Ilha de Cabo Frio (Arraial do Cabo, Rio de Janeiro). 
Hypselodoris lajensis Troncoso, García and Urgorri, 1998 (Fig. 1K)

Hypselodoris picta lajensis Troncoso, García and Urgorri, 1998.

Material examined. (Length in living animals): 1 specimen of length $30 \mathrm{~mm}$, Laje de Santos, Bahía de Santos (São Paulo); depth $25 \mathrm{~m}$. Material examined from the Museo de Zoologia de la Universidad de São Paulo (length in preserved animals): 1 specimen of length $18 \mathrm{~mm}$, registration number MZUSP 32417, Laje de Santos, depth $18 \mathrm{~m}(16 / 04 / 00)$; 2 specimens of length 18, $21 \mathrm{~mm}$, registration number MZUSP 39130, Cabo Frio (Rio de Janeiro), depth $10 \mathrm{~m}$ (2002); 3 specimens of length $25,25,28 \mathrm{~mm}$, registration number MZUSP 32879, Reserva Marinha do Arvoredo, depth $7.3 \mathrm{~m}(13 / 10 / 00)$.

External morphology (Fig. 1K) and anatomy is the same as in the original description of the subspecies (Troncoso et al., 1998).

Remarks. This specimen was described in detail by Troncoso et al. (1998), who compared it with the five subspecies of Hypselodoris picta (Schultz, 1836) suggested by Ortea et al. (1996), and summarised the most important features of this species. $H$. picta has numerous colour types. Troncoso et al. (1998) considered this specimen as a new subspecies because some characteristics were the same as those in $H$. picta, but $H$. lajensis has distinctive features that enable them to be distinguished.

$H$. picta has three broken yellow lines on dorsum ending in the gill sheath; only the median line follows behind the gill (Ortea et al., 1996). In contrast, $H$. lajensis has five longitudinal yellow lines running from the head to the gill pocket and these lines run to the anterior and posterior mantle edge. This feature was also observed in the specimens deposited in the Museo de Zoologia de la Universidad de São Paulo identified as Hypselodoris picta lajensis. Both species have blue rhinophores, without yellow marks, and the rhinophoral sheath is completely or partly surrounded by a yellow ring; besides this, around the gill there is no yellow ring. However $H$. picta has gills with yellow rachis, whereas $H$. lajensis has deep blue-violet gills. On the hyponotum of $H$. picta there is a yellow line and numerous marks and circles. H. lajensis has four or five yellow broken lines on each side of body. The reproductive system in $H$. picta has a short and broad deferens duct with a very long and coiled prostatic part; $H$. lajensis, on the other hand, has a deferens duct differentiated into three regions: a preprostatic narrow portion, a long and coiled prostatic portion and a long narrow and coiled postprostatic portion. We dissected a specimen of $H$. picta lajensis deposited in the museum of São Paulo, and compared its radula and reproductive system with the original description of the subspecies. We saw that they are very similar.

For these reasons, after the revision of Hypselodoris picta lajensis and a comparison with the specimens of $H$. picta, we concluded that the above-mentioned subspecies is a separate species called Hypselodoris lajensis.

Distribution. Laje de Santos, Bahia de Santos (Troncoso et al., 1998), Laje de Santos, Cabo Frio and Reserva Marinha do Arvoredo (present paper).

\section{ACKNOWLEDGEMENTS}

We are very grateful to Dr. Ricardo S. Absalão, Dr. Paulo Marcio Costa and Dr. Renata Gomes for assistance in nudibranch collecting, and to Rear Admiral Napoleao Gomes, director of the Instituto de Estudos do Mar of the Brazilian Navy, for facilitating transport by boat in the zone of Arraial do Cabo. This paper was partially supported by the projects PHB2002-0045-PC and CGL2004-20366E/BOS, of the Ministerio de Educación y Ciencia (MEC, Spain) and by a project supported by the Agencia Española de Cooperación Internacional (AECI) from 1998 to 2000.

\section{REFERENCES}

Bandel, K. - 1976. Egg masses of 27 Caribbean opisthobranchs from Santa Marta, Colombia. Stud. Neotrop. Fauna, 11: 87118.

Bertsch, H. - 1988. Anatomy and zoogeography of Glossodoris sedna and Chromodoris grahami (Opisthobranchis: Nudibranchia) in the Tropical Western Atlantic and Caribbean. Veliger, 30(4): 395-399.

Collier, C.L. and W.M. Farmer. - 1964. Additions to the nudibranch fauna of the East Pacific and the Gulf of California. Trans. San Diego Soc. Nat. Hist., 13(19): 377-396.

Edmunds, M. - 1981. Opisthobranchiate Mollusca from Ghana: Chromodorididae. Zool. J. Linn. Soc., 72: 175-201.

Edmunds, M. - 1982. Speciation in chromodorid nudibranchs in Ghana. Malacologia, 22(1-2): 515-522.

Edmunds, M. and H. Just. - 1985. Dorid, Dendrodotid and Arminid Nudibranchiate Mollusca from Barbados. J. Molluscan Stud., 51: $52-63$.

García-Gómez, J.C. - 2002. Paradigmas de una fauna insólita. Los moluscos opistobranquios del Estrecho de Gibraltar. Instituto de Estudios Gibraltareños. Algeciras (Cádiz).

Humann, P. - 1992. Reef creatures Identification. Florida, Caribbean, Bahamas. Ned DeLoach, New world Publications, Jacksonville, Florida.

Ihering, H. von. -1886 . Die Opisthobranchien der brasilianischen Küsten. Jahrbuch der Deutschen malakologischen Gesellschaft, 13: 223-240.

MacFarland, F.M. - 1909. The opisthobranchiate Mollusca of the 
Branner-Agassiz expedition to Brazil. Leland Stanford Jr. Univ. Publ., 2: 1-104, pls. 1-19.

MacFarland, F.M. - 1966. Studies of Opisthobranchiate Mollusks of the Pacific coast of North America. Mem. Calif. Acad. Sci.

Marcus, Er. - 1955. Opisthobranchia from Brazil (1). Bol. Fac. Fil. Cienc. Univ. S. Paulo, Zool., 20: 89-261.

Marcus, Er. - 1957. On Opisthobranchia from Brazil (2). J. Linn. Soc. Lond. Zool., 43: 309-486.

Marcus, Er. - 1958. On western Atlantic opisthobranchiate gastropods. Am. Mus. Novit., 1906: 1-82.

Marcus, Ev. - 1970. Opisthobranchs from Northern Brazil. Bull. Mar. Sci., 20(4): 922-951.

Marcus, Ev. - 1976. Opisthobranchia von Santa Marta, Colombia. Stud. Neotrop. Fauna, 11: 119-150.

Marcus, Ev. - 1977. An annotated checklist of the Western Atlantic warm water opisthobranchs. J. Molluscan Stud., Suppl. 4: 1-22.

Marcus, Ev. and Er. Marcus. - 1963. Opisthobranchs from the Lesser Antilles. Stud. Fauna Curacao Caribb. Is., 19(79): 1-76.

Marcus, Ev. and Er. Marcus - 1967a. Ámerican opisthobranch mollusks. Stud. Trop. Oceanogr. Miami, 6: 1-256.

Marcus, Ev. and Er. Marcus. - 1967b. Tropical American opisthobranch. Stud. Trop. Oceanogr. Miami, 6: 139-248.

Marcus, Ev. and Er. Marcus. - 1967c. Opisthobranchs from the Southwestern Caribbean Sea. Bull. Mar. Sci., 17(3): 597-628.

Matthews, H.R. and M. Kempf. - 1970. Moluscos marinhos do Norte e Nordeste do Brasil. II - Moluscos do Arquipélago de Fernando de Noronha (com algumas referências ao Atol das Rocas). Arq. Cienc. Mar., 10(1): 1-53.

Ortea, J., E. Martínez and G. Villani. - 1994. Estudio comparado de animales de Nanuca sebastiani Marcus, 1957 (Mollusca: Nudibranchia: Aeolidacea) recolectados en aguas de Cuba y Brasil. Avicennia, 1: 131-136.

Ortea, J., A. Valdés and J. Espinosa. - 1994. North Atlantic nudibranchs of the Chromodoris clenchi colour group (Opisthobranchia: Chromodorididae). J. Molluscan Stud., 60: 237-248

Ortea, J., A. Valdés and J.C. García-Gómez. - 1996. Revisión de las especies atlánticas de la familia Chromodorididae (Mollusca: Nudibranchia) del grupo cromático azul. Avicennia, Suppl. 1: $1-165$.

Padula, V. and R.S. Absalão. - 2005. Primeiro registro de Babakina festiva (Roller, 1972) (Mollusca: Nudibranchia) no Atlântico Sul. Biociências, 13 (1): 99-101.

Pola, M., J.L. Cervera and T.M. Gosliner. - 2005. A new species of Tambja Burn, 1962 (Mollusca, Nudibranchia, Polyceridae) from southern Brazil. J. Mar. Biol. Ass. U.K., 85(3): 979-984.

Rios, E. - 1994. Seashells of Brazil. Editora da Fundaçao Universidade do Rio Grande: Rio Grande.

Rudman, W.B. - 1983. The Chromodorididae (Opisthobranchia: Mollusca) of the Indo-West Pacific: Chromodoris splendida, $C$. aspersa and Hypselodoris placida colour groups. Zool. J. Linn. Soc., 78: 105-173.

Rudman, W.B. - 1984. The Chromodorididae (Opisthobranchia: Mollusca) of the Indo-West Pacific: a review of the genera. Zool. J. Linn. Soc., 81: 115-273.

Rudman, W.B. - 1991. Purpose in pattern: the evolution of colour in chromodorid nudibranchs. J. Molluscan Stud., 57: 5-21.

Russell, H.D. - 1935. Some nudibranch of Bermuda, with a description of a new species. Nautilus, 49: 59-61.

Schrödl, M. and S.V. Millen. - 2001. Revision of the nudibranch gastropod genus Tyrinna Bergh, 1898 (Doridoidea: Chromodorididae). J. Nat. Hist., 35: 1143-1171.

Thompson, T.E. - 1980. Jamaican Opisthobranch Molluscs II. J. Molluscan Stud., 46: 74-99.

Thompson, T.E. and G.H. Brown. - 1984. Biology of Opisthobranch molluscs. Volume II. The Ray Society.

Troncoso, J.S., F.J. García and V. Urgorri. - 1998. Anatomical data on a rare Hypselodoris picta (Schultz, 1836) (Gastropoda, Doridacea) from the coast of Brazil with description of a new subspecies. Bull. Mar. Sci., 63(1): 133-141.

Received April 25, 2005. Accepted July 3, 2006.

Scient. ed.: J.D. Ros

Published online November 2, 2006. 